кафедры «Прикладная экология», Казанский (Приволжский) федеральный университет. Россия.

420008, г. Казань, ул. Кремлевская, д. 18.

Тел.: (843) 236-50-62; e-mail: ecology@kpfu.ru.

Хаммадов Наиль Ильдарович, канд. биол. наук, ведущий научный сотрудник лаборатории биохимии и молекулярно-генетического анализа, Федеральный центр токсикологической, радиационной и биологической безопасности. Россия.

Фаизов Тагир Хадиевич, $\partial-p$ вет. наук, зав. лаборато- рией биохимии и молекулярно-генетического анализа, Федеральный центр токсикологической, радиационной и биологической безопасности. Россия.

420075, г. Казань, ул. Научный городок-2.

Тел.: (843) 239-53-20; e-mail:vnivi@mail.ru.

Ключевые слова: Apis mellifera L.; мультипраймерная ПЦР; вирус мешотчатого расплода; вирус острого паралича; вирус черного маточника; вирус деформации крыла.

\title{
METAGENOMIC ANALYSIS FOR HONEY BEE VIRUSES INDICATION BY MULTIPRIMER PCR
}

Khammadova Alfiya Vasilevna, Magistrandt, Kazan Federal University. Russia.

Mukminov Malik Nilovich, Doctor of Biological Sciences, Professor of the chair "Applied Ecology", Kazan Federal University. Russia.

Shuralev Eduard Arkadevich, Candidate of Veterinary Sciences, Leading Researcher, Laboratory of biochemistry and molecular genetics, Federal Center for Toxicological, Radiation and Biological Safety. Russia.

Khammadov Nail Ildarovich, Candidate of Biological Sciences, Leading Re-searcher, Laboratory of biochemistry and molecular genetics, Federal Center for Toxicological, Radiation and Biological Safety. Russia.

Faizov Tagir Khadievich, Doctor of Veterinary Sciences, Federal Center for Toxicological, Radiation and Biological Safety. Russia.
Keywords: Apis mellifera L.; multiprimer PCR; Sacbrood virus; Acute bee paralysis virus; Black queen cell virus; Deformed wing virus.

The purpose of this work was the design of primers for indication and identification of the causative agents of bee viral diseases (sacbrood, acute bee paralysis, black queen cell, deformed wing) by multiprimer PCR. Using the bioinformatics techniques, the design of the oligonucleotide primers was performed, which had similar annealing temperatures $\left(60^{\circ} \mathrm{C}\right)$ that allows each of the viruses to be identified under the same PCR conditions. Most of the known strains and isolates of these viruses are amplified with designed complex of oligonucleotide primers. Nucleotide sequences of primers and universal positive control allow genetic identification each of the presented biopathogens under the same PCR conditions at multiprimer format.

удк 636.2.034

\section{ПОЛИМОРФИЗМ ГЕНА СТЕАРИЛ-КОА КОДЕСАТУРЗЫ (SCD1) ДЛЯ ЛОКУСОВ КОЛИЧЕСТВЕННЫХ ПРИЗНАКОВ МОЛОЧНОЙ ПРОДУКТИВНОСТИ}

\author{
ЮЛЬМЕТЬЕВА Юлиана Рустэмовна, ТатНИИСХ ФИЦ КазНЦ РАН \\ САФИНА Наталья Юрьевна, ТатНИИСХ ФИЦ КазНЦ РАН; Казанская государственная \\ академия ветеринарной медицины имени Баумана
}

ШАРАФУТДИНОВ Газимзян Салимович, Казанский государственный аграрный университет ШАКИРОВ Шамиль Касымович, ТатНИИСХ ФИЦ КазНЦ РАН

\begin{abstract}
Повышения эффективности племенной работы невозможно достичь традиционными методами оценки племенной иенности. Применение днк-технологий открывает новые возможности в определении наследственной информации о животном, что позволит провести оценку, не дожидаясь собственной продуктивности. Поэтому иель наших исследований - поиск ассоциативных связей полиморфизма гена SCD1 с молочной продуктивностъю. Установлена генетическая характеристика структуры популяции, при этом распределение по частоте встречаемости соответствовало 0,54 (C) и 0,46 (T), в разрезе полиморфизма генотипов распределение составило 218 гол. с генотипом СС (20,2 \%), 739 гол. с генотипом СТ (68,6 \%) и 121 гол. с генотипом TT (11,2\%). Показано, ито коровы с генотипом SCD ${ }^{\text {тт }}$ иеют достоверное превосходство по надоенному молоку в динамике первых трех лактаций, а также по содержанию белка в молоке. Однако выход молочного жира был выше у животных с генотипом SCD1 ${ }^{c c}$.
\end{abstract}

Введение. Совершенствование селекционноплеменной работы в молочном скотоводстве осуществляется системой мероприятий, в которой большое значение имеет точность определения племенной ценности всего поголовья стада. Повышения точности оценки можно достичь, применяя методы ДНК-анализа, посредством которого определяется наследственная информация о животном [4].
Преимущество ДНК-технологий заключается в том, что можно определить генотип животного независимо от пола, возраста и физиологического состояния, что значительно повышает интенсивность селекции и снижает генерационный интервал между поколениями $[1,3]$.

Ген SCD1 кодирует ключевой фермент синтеза жирных кислот стерол-СоА десатуразу (дельта-9-десатуразу). Установлено, что однонуклеотидный по- 
лиморфизм С на Т в 5-м экзоне гена SCD (c:878C > T) приводит к замене аминокислоты валин на аланин в продукте гена и влияет на состав жирных кислот в жировой ткани животных. Установлено, что лучшими вкусовыми качествами обладает мясо животных, несущих в своем генотипе аллель С, за счет более высокого содержания мононенасыщенных жирных кислот [5].

Цель исследования - поиск ассоциативных связей полиморфизма гена SCD1 с молочной продуктивностью.

Методика исследований. Исследования проводили в условиях СХПК племзавод им. Ленина Атнинского р-на Республики Татарстан (1078 телок случного возраста и коров голштинской породы). Из числа первотелок и высокопродуктивных коров были сформированы опытные группы в соответствии с установленными генотипами животных и проведены исследования их хозяйственно-полезных признаков. В изучаемой популяции генотипированных по маркерам продуктивности и устойчивости животных были сформированы группы коров первой законченной лактации (560 гол.), второй законченной лактации (197 гол.) и третьей лактации (32 гол.).

Анализ происхождения, продуктивности коров производили с помощью программного пакета «СЕЛЭКС 5.63» (АРМ Плинор, Санкт-Петербург). Молочную продуктивность определяли путем проведения контрольных доек. Качество молока анализировали на приборе «Лактан 1-4» в соответствии с инструкциями производителя. Частоту встречаемости генотипов определяли по формуле Е.К. Меркурьевой [2]:

$$
p=\frac{n}{N}
$$

где $p$ - частота определения генотипа; $n$ - количество особей, имеющих определенный генотип; $N$ - число особей.

Частоту отдельных аллелей определяли по формуле Е.К. Меркурьевой [2]:

$$
\begin{aligned}
& p_{A}=\frac{2 n A A+n A B}{2 N}, \\
& q_{A}=\frac{2 n B B+n A B}{2 N},
\end{aligned}
$$

где $p_{A}$ - частота аллеля $\mathrm{A} ; q_{A}$ - частота аллеля $\mathrm{B} ; n-$ количество голов заданного генотипа; $N$ количество голов в изучаемой популяции.

Экспериментальный материал обрабатывали по стандартным программам вариационной статистики.

Результать исследований. В результате ПЦР-ПДРФ тестирования по гену SCD1 было выявлено 3 генотипа - СС, СТ, ТТ. Установлена генетическая характеристика структуры популяции, при этом распределение по частоте встречаемости соответствовало 0,54 (С) и
0,46 (T), в разрезе полиморфизма генотипов распределение составило 218 гол. с генотипом CС (20,2\%), 739 гол. с генотипом СТ (68,6\%) и 121 гол. с генотипом ТТ $(11,2 \%)$, рис. 1.

Наши более ранние исследования (258 гол.) совпадают

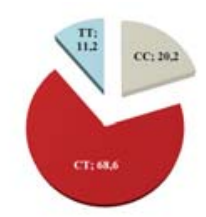

$=\infty$ $m \mathrm{CT}$
$=\mathrm{TT}$

Puc. 1. Yacmoma встречаемости генотипов гена SCD1 по частотам распределения генотипов, при этом в стаде животных с генотипом СС оказалось 38,4 \%, СТ - 45,7 \%, ТТ - 15,9\% [5].

Анализ динамики молочной продуктивности по первым трем стандартным лактациям в разрезе полиморфизма гена SCD1 показал, что высокие результаты характерны для животных с генотипом $\mathrm{SCD}^{\mathrm{Cc}}$. В сравнении с первотелками, несущими генотип SCD ${ }^{\mathrm{TT}}$, выше на 44 кг; по второй лактации разница увеличивалась до 472 кг, по третьей до 2767 кг $(P<0,05)$, рис. 2. При этом животные с ценным генотипом имели и более высокую белковомолочность, что на 0,09 \% выше особей с гетерозиготным генотипом $(P<0,001)$, или в пересчете по количетсву молочного белка на 20,1 кг $(9,2 \%)$, рис. 3 .

Результаты подобных исследований носят противоречивый характер. Так, в итальянской популяции голштинского скота N.P.P. Macciotta и

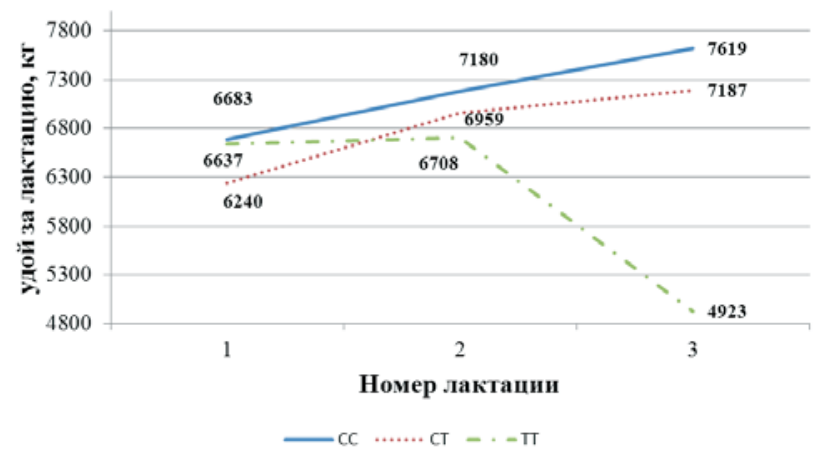

Рис. 2. Ассоциация полиморфизма гена-маркера SCD1 с динамикой удоя за первые три стандартные лактации

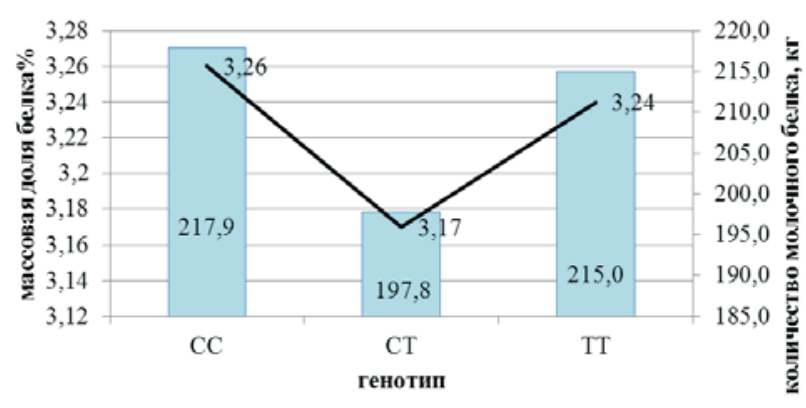

количество молочного белка, кг — массовая доля белка, \%

Рис. 3. Ассоциация полиморфизма гена-маркера SCD1 с содержанием массовой доли и количества белка коров-первотелок 


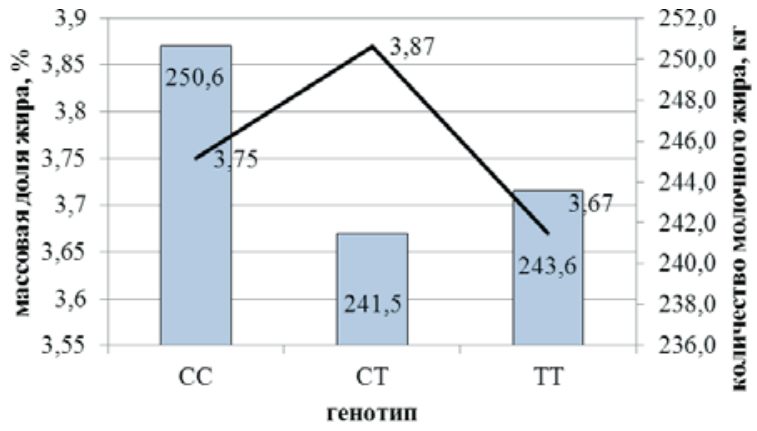

$\square$ молочный жир, кг — массовая доля жира, \%

Рис. 4. Ассоциация полиморфизма гена-маркера SCD1 с жирномолочностью коров-первотелок

др. установили влияние генотипа SCD1 на удой и выход молочного жира, от коров с генотипом ТT получено больше молока и молочного белка, чем от сверстниц с генотипом СС [6]. В нашем исследовании высокой жирномолочностью отличались первотелки с гетерозиготным генотипом, у которых содержание массовой доли жира в молоке выше на 0,2 \%, чем у особей гомозиготных по аллелю Т. Однако в пересчете на молочный жир его выход был выше у животных с генотипом SCD1cc, разница со сверстницами с генотипом $S C D 1^{\mathrm{CT}}$ составила 9,1 кг, или 3,6 \% (рис. 4).

Заключение. Анализ распределения частот встречаемости аллелей по гену SCD1 показал преобладание в популяции голштинского скота в Республике Татарстан аллеля C $(0,54)$. Высокая продуктивность характерна для животных с генотипом $\mathrm{SCD}^{\mathrm{cc}}$, что в сравнении с первотелками, несущими генотип SCD ${ }^{\mathrm{TT}}$, выше на 44 кг, по второй лактации разница увеличивалась до 472 кг, по третьей до 2767 кг.

\section{СПИСОК ЛИТЕРАТУРЫ}

1. Использование полиморфизма ДНК и генов в селекции сельскохозяйственных животных / А.Ф. Яковлев [и др.] // Современные методы генетики и селекции в животноводстве: материалы Междунар. науч. конф. - СПб.: ВНИИГРЖ, 2007. - С. 18-22.

2. Меркурьева Е.К., Шангин-Березовский Г.Н. Генетика с основами биометрии. - М.: Колос, 1983. - 400 с.

3. Малкин М.Н. Молочная продуктивность и воспроизводительные качества коров красно-пестрой породы, полученных при скрещивании и от разведения «в себе» // Аграрный научный журнал. - 2016. - № 8. C. 25-28.

4. О состоянии молочного животноводства в Российской Федерации / Г. Шичкин [и др.] // Молочное и мясное скотоводство. - 2010. - № 7. - С. 2-6.

5. Сафина Н.Ю., Юльметьева Ю.Р., Шакиров Ш.К. Мониторинг полиморфных вариантов гена СтеарилКоА Кодесатурзы (SCD1) крупного рогатого скота в зависимости от направления продуктивности // Ученые записки Казанской государственной академии ветеринарной медицины им. Н.Э. Баумана. - 2018. № 233. - C. 136-141.

6. Associacition Between a Polimorphism at the Stearoyl CoA Desaturase Locus and Milk Production Traits in Italian Holstenins/N.P.P. Macciotta, M. Mele, G. Conte [et all.] // Journal of Dairy Science, 2008, Vol. 91, No. 8, P. 3184-3189.

7. Kelsey J.A., Corl B.A., Collier R.J., Bauman D.E. The effect of breed, parity and stage of lactation on conjugated linoleic acid (CLA) in milk fat from dairy cows. // J. Dairy Sci., 2003, 86: 2588-2597.

Юльметьева Юлиана Рустэмовна, канд. биол. наук, старший науиный сотрудник, ТатНИИСХ ФИЦ КазНЦ РАН. Россия.

420059, г. Казанъ, Оренбургский тракт, 48.

Тел.: (843) 277-81-17; pochtovik81@mail.ru.

Сафина Наталья Юрьевна, младший научный сотрудник, ТатНИИСХ ФИЦ КазНЦ РАН; аспирант кафедры «Технология животноводства», Казанская государственная академия ветеринарной медииины имени Н.Э. Баумана. Россия.

420029, г. Казань, Сибирский тракт, 35.

Тел.: (843) 273-97-14.

Шарафутдинов Газимзян Салимович, $\partial-p c$. $-x$. наук, проф. кафедры «Животноводство», Казанский государственный аграрный университет. Россия.

420015, г. Казанъ, ул. К. Маркса, 65.

Тел.: (843) 236-66-51; gazimsharaf_kgay@mail.ru.

Шакиров Шамиль Касымович, $\bar{\partial}-p c$.-х. наук, проф., главный научный сотрудник, ТатНИИСХ ФИЦ КазНЦ РАН. Россия.

420059, г. Казанъ, Оренбургский тракт, 48.

Тел.: (843) 277-81-17; intechkorm@mail.ru.

Ключевые слова: корова; удой; ген SCD1; полиморфизм; молочный белок; молочный жир.

\section{POLYMORPHISM OF THE STEARYL-COA GENE OF KODESATURZA (SCD1) FOR LOCI OF QUANTITATIVE SIGNS OF MILK PRODUCTIVITY}

Yulmeteva Yuliana Rustemovna, Candidate of Biological Sciences, Senior Re-searcher, Tatar Research Institute of Agriculture, FRC Kazan Scientific Center of RAS. Russia.

Safina Natalya Yurevna, Junior Researcher, Tatar Research Institute of Agriculture, FRC Kazan Scientific Center of RAS; Postgraduate of the chair "Cattle Breeding Technology", Kazan State Academy of Veterinary Medicine named after N.E. Bauman. Russia.

Sharafutdinov Gazimzyan Salimovich, Doctor of Agricultural Sciences, Professor of the chair "Cattle Breeding”, Kazan State Academy of Veterinary Medicine named after N.E. Bauman. Russia.

Shakirov Shamil Kasimovich, Doctor of Agricultural Sciences, Professor, Chief Researcher, Tatar Research Institute of Agriculture, FRC Kazan Scientific Center of RAS. Russia.

Keywords: cow; milk; SCD1 gene; polymorphism; milk protein; milkfat.
At present, increasing the effectiveness of breeding work cannot be achieved by traditional methods of assessing breeding value. In this regard, the use of DNA technology opens up new opportunities in determining hereditary information about the animal, which will allow for an assessment, without waiting for its own productivity. Therefore, the purpose of our studies was to search for associative links of polymorphism of the SCD1 gene with dairy productivity. The genetic characteristic of the population structure was established, with the frequency distribution corresponding to 0.54 (C) and 0.46 (T), in the genotypes polymorphism the distribution was 218 with the CC genotype (20.2\%), 739 with the CT genotype (68.6\%) and 121 heads with TT genotype (11.2\%). The conducted studies show that cows with the SCDTT genotype have a significant superiority in milk of milk in the dynamics of the first three lactations, as well as high protein content in milk. However, the yield of milk fat was higher in animals with the genotype SCD1CC 